\title{
Process-based erosion modelling for shoreline rehabilitation design of a coal mine pit lake
}

\author{
CD McCullough Mine Lakes Consulting, Australia
}

A van Rooijen Deltares, Australia

DS van Maren Deltares, Netherlands

\begin{abstract}
Mine pit lakes are a common feature of open cut mine closures that extend below the local groundwater levels. Due to the relatively steep lake bottom profiles compared to natural lakes, shoreline stability remains a significant limitation for the long-term sustainability of many pit lakes, potentially impacting upon highwall geotechnical stability, revegetation success, water quality and proposed end uses including wildlife habitat, aesthetics and recreation. However, although a potential issue for long-term pit lake closure planning and management, there is currently very little information available on pit lakeshore erosion, including potential erosion rates and extent.
\end{abstract}

The ENGIE Hazelwood Coal Mine project is located in the Latrobe Valley, Victoria. The site has ceased operations and is currently in closure work phase. With approximately $16 \mathrm{~km}$ of pit lake perimeter, the effect of the final pit lake shoreline design on wave-induced shoreline erosion was identified as a key area requiring further study.

This innovative study used the process-based hydro-morphodynamic models Delft3D to predict final pit lake shoreline erosion at the Eastern Batter (EB) domain region of the pit void. Shoreline erosion modelling was undertaken for three erosion treatments over a total of 10 scenarios.

1. Effect of sediment type (clays, sands and clay/sand mixtures).

2. Effect of shore slope angle (design angle of $17^{\circ}$ from horizontal, to a lower $12^{\circ}$ and steeper $22^{\circ}$ ).

3. The effect of prevailing winds compared to episodic storm winds.

Pit lake shoreline erosion modelling was found to be a useful design tool for to study pit lake shoreline developments. Further model findings were that relatively gentle $\left(12^{\circ}\right)$ slopes did not show substantially decreased erosion rates compared to design $\left(17^{\circ}\right)$ slopes. However, relatively steep $\left(22^{\circ}\right)$ slopes showed substantially greater erosion.

Erosion rates were strongly influenced by sediment properties, which constituted the biggest uncertainty in the modelling. Lowest erosion rates were for cohesive grey clays, highest erosion rates for sands and erosion rates of mixed sediments were in-between. Eroded sands were also deposited nearby at slightly deeper water, thereby reducing shoreline slopes over longer timescales. However, eroded clays were dispersed throughout the lake, preventing an erosion/deposition equilibrium being reached.

Short-term storm events simply mimicked erosion patterns of longer duration prevailing wind events. Consequently, slope and sediment characteristic choices to mitigate prevailing wind effects may be similar to those used for mitigating event-driven erosion.

Keywords: mine closure, pit lakes, waves, erosion, numerical modelling, Delft3D 


\section{Introduction}

\subsection{Pit lakes}

Mine pit lakes are a common feature of open cut mine closures that extend below the local groundwater levels (Castendyk \& Eary 2009). Globally metal mines tend to have steeper sided lakes and coal mines relatively shallower lakes (Schultze et al. 2016). Pit lakes can represent the highest environmental risk closure landform for many mines (Doupé \& Lymbery 2005; McCullough 2016).

Due to the relatively steep lake bottom profiles compared to natural lakes, shoreline stability remains a significant limitation for the long-term sustainability of many pit lakes, potentially impacting upon highwall geotechnical stability, revegetation success, water quality and proposed end uses including wildlife habitat, aesthetics and recreation (McCullough \& Lund 2006; McCullough \& van Etten 2011) (Figure 1). However, although a potential issue for long-term pit lake closure planning and management, there is currently very little information available on pit lake shore erosion, including potential erosion rates and extent (van Etten 2011).

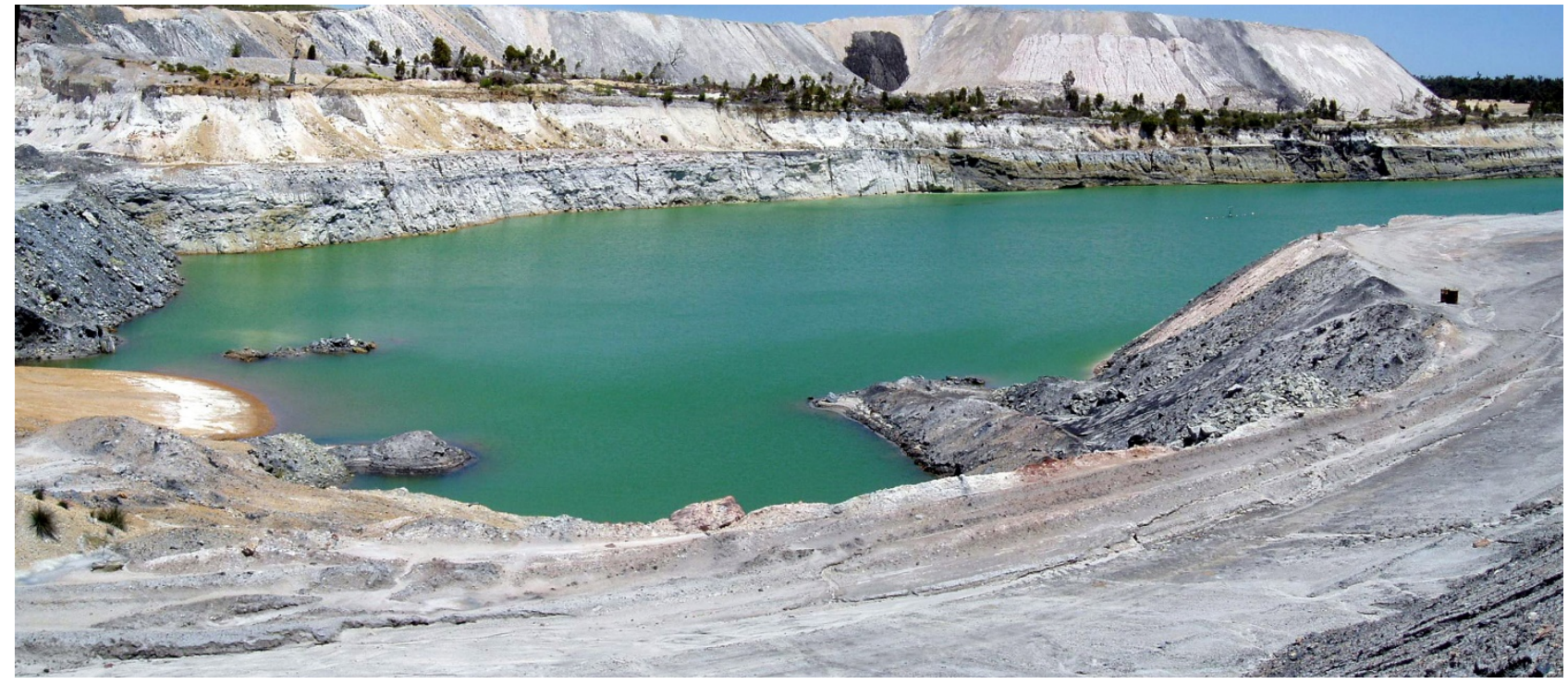

Figure 1 Extensive shoreline erosion in a Western Australian coal pit lake (McCullough et al. 2010)

\subsection{Waves and shoreline erosion}

Wave action is a phenomenon of natural lakes and contributes to ecosystem function processes such as nutrient cycling and creating habitat diversity. However, a fundamental limitation facing the rehabilitation and sustainable closure of pit lakes remains shoreline stability (Lund \& McCullough 2011).

The strength of pit wall materials may change during filling because of reduced normal stress on the materials near the pit walls or as a result of water flow along fractures or geologic structures. Rising lake water levels may also cause erosion of softer deposits, leading to undercutting and overhanging zones to form. Small pit slope failures are therefore not unusual during the pit filling process and may also occur once the final lake level has been established (Read \& Stacey 2009).

It is often assumed that pit lakes will follow an evolution from young to mature lakes, resulting in lakes with a well-developed ecosystem (Kalin \& Geller 1998). However, pit lakes even decades old frequently show still very high rates of shoreline erosion (Vandenberg \& McCullough 2017). The typically steep sides, unconsolidated shoreline materials and lack of littoral and riparian vegetation means that pit lake shorelines are exposed and readily eroded by wind waves (Figure 2) (van Etten 2011). In a circular process over time, constant erosion can inhibit colonisation of littoral and riparian zones, leading to further erosion (de Lange et al. 2018). 
Steep, eroding pit lake shorelines reduce end use opportunities and values (McCullough et al. 2018) and present a significant risk (Ross \& McCullough 2011). Shoreline erosion can also erode soil covers and backfill exposing potentially acid forming (PAF) waste materials and void shell exposures previously buried to prevent oxidation and acidity generation. Suspended sediments can occlude water visibility and, when settled, smother littoral invertebrate and aquatic macrophyte communities. Erosion will continue until a new subaqueous equilibrium topography can then erode the surrounding catchment further, impacting upon terrestrial revegetation outcomes.

Rehabilitation of post-mining terrestrial landforms to provide restored and sustainable end uses has now become a well-researched (and generally successful) practice that borrows from both disciplines of ecology and engineering. Indeed, post-mining rehabilitated human uses and ecosystems are a significant landscape feature in many regions with mining history. However, this landscape restoration typically ceases at the edge of open cut/cast pits, except where backfill and/or landscaping directly incorporate the pit back into the surrounding terrestrial ecosystem (McCullough et al. 2009). Nevertheless, although a significant issue for pit lake closure planning and management, there is very little information available on determination and management of pit lakeshore erosion.

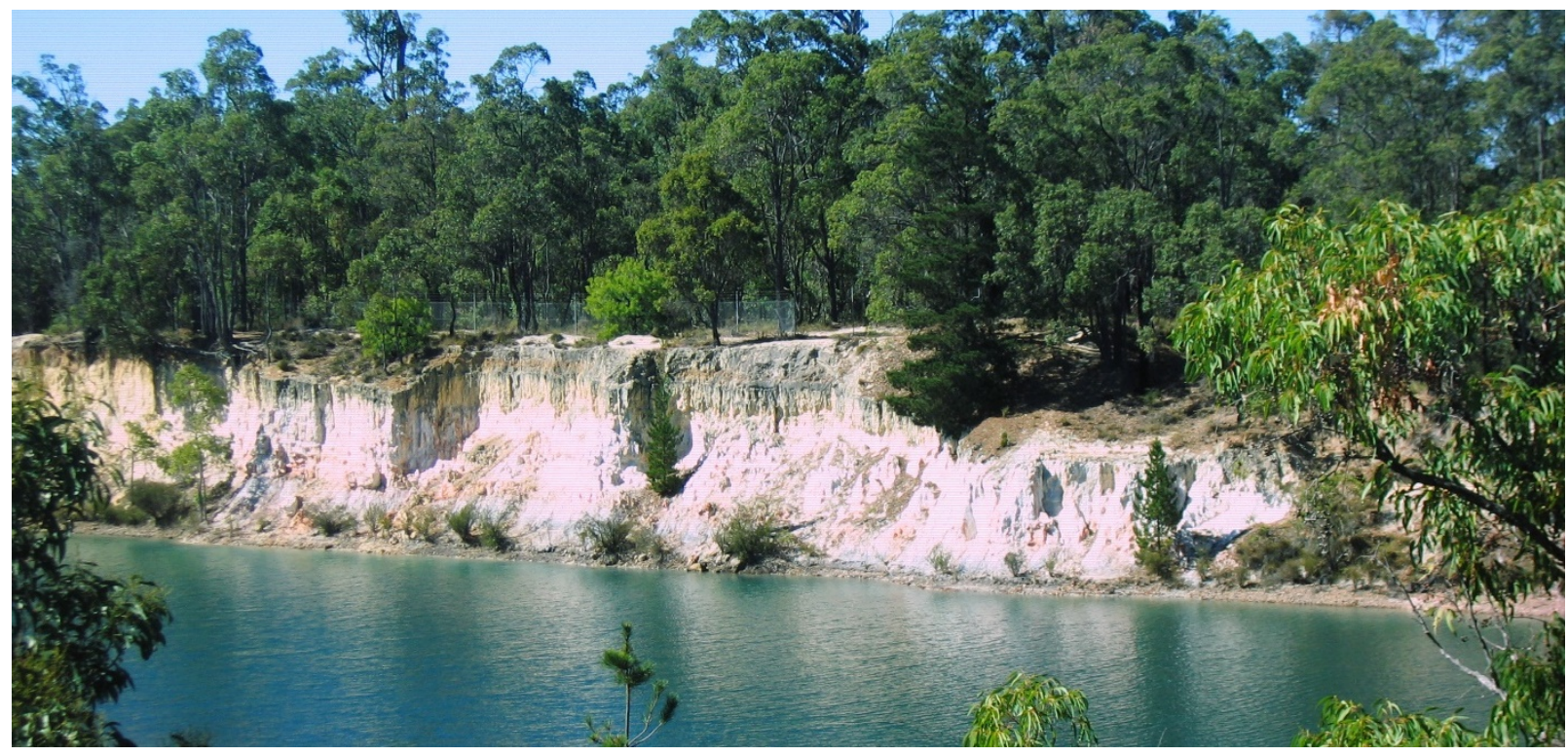

Figure 2 Steep shorelines in a Western Australian coal pit lake (McCullough et al. 2010)

\subsection{Modelling}

The shoreline morphometry of a pit lake is determined by the original void shape and modified by any backfilling and shaping. Orientation of the lakes largest dimensions relative to prevailing winds influence the fetch and therefore wind induced wave action.

The hydrodynamics of wind-forced waves are well understood and models are readily able to estimate wave characteristics for deep, open water and continuous shorelines. However, wave height alone does not determine whether erosion will occur or not, making it difficult to develop general guidelines for the relative importance of waves on shoreline erosion (Gourlay 2011). For this reason, a morphodynamic model accounting for waves and their resulting shoreline erosion was established to allow evaluation of wave conditions and sediment properties of the Eastern Batter (EB) domain of the proposed Hazelwood pit lake for which final perimeter regrading was being planned.

The morphodynamic model in this current study is set-up using the Delft3D modelling software (version 4.03). Delft3D is an established open source 3D modelling suite for investigating hydrodynamics, sediment transport and morphology for various aquatic environments (Deltares 2014). Although primarily used in marine, estuarine and riverine environments, as well as natural lakes, Delft3D has potential as a tool for also studying mine lakeshore erosion. 
The model includes the following components:

- FLOW - to simulate currents and water level changes resulting from wind or waves.

- WAVE - to simulate the propagation and dissipation of waves, including generation by wind.

- SED/MOR - to simulate the effect of current- and wave-induced bed shear stress on sediment transport and morphology.

The model components were coupled in 'online' mode, i.e. simulations are based on an integrated model where information is exchanged between all model components at set times throughout the simulation.

\section{$2 \quad$ Aims and methodology}

\subsection{Study site}

The ENGIE Hazelwood Coal Mine project is located in the Latrobe Valley, Victoria (Figure 3, top left). The site has ceased operations and is currently undergoing final closure planning and rehabilitation. The end land use for the site, although not finalised, is proposed a mix of park land, a large pit lake and agricultural and industrial land. Earthworks for the EB pit wall domain were planned for September 2018 (Figure 3, bottom right). However, through the development of the rehabilitation plan by ENGIE, pit lake shoreline wave erosion management for this area was identified as a key area requiring additional study. Shoreline erosion risk is a significant consideration for regulators, where the potential need for extensive and cost-prohibitive armouring for shorelines was identified during the Hazelwood Fire Inquiry (Hazelwood Mine Fire Inquiry 2016). However, although shoreline revegetation trials are currently being undertaken within Valley, no erosion modelling is currently being undertaken in the Latrobe Valley.

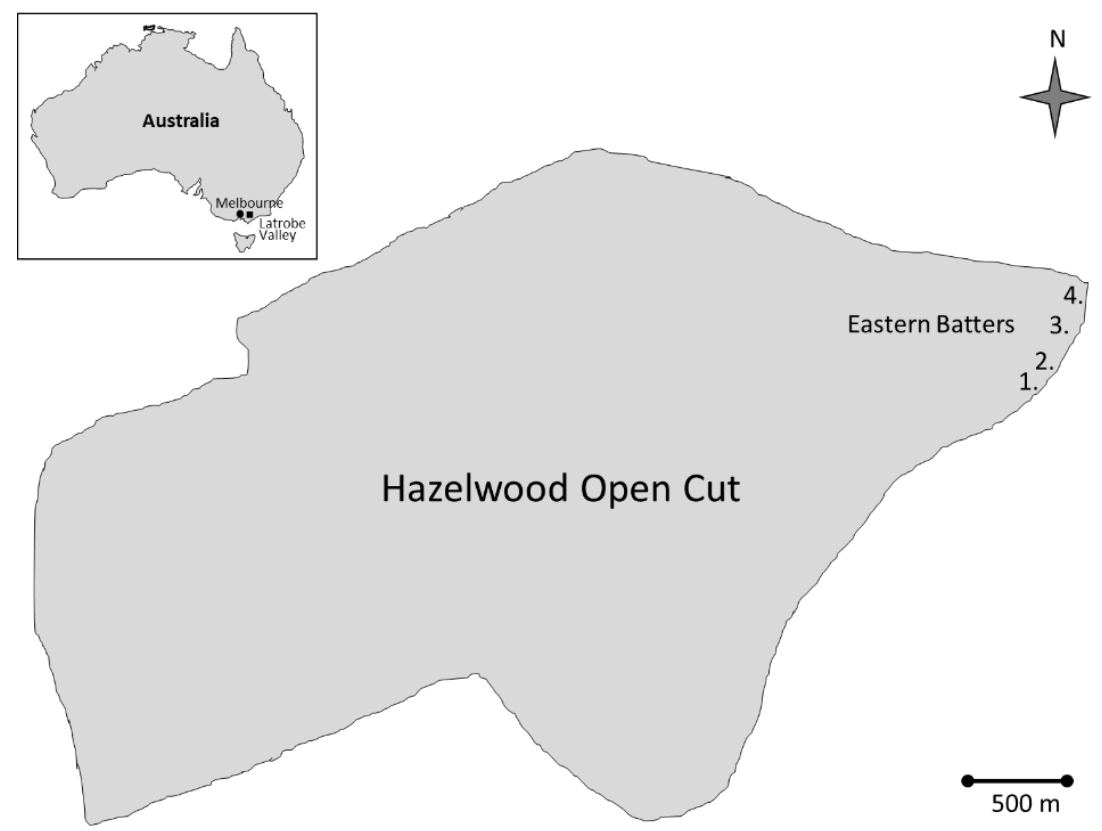

Figure 3 Study site locations and sampling positions 
The unrehabilitated section of the Hazelwood EB presented as a series of 10-20 m high batters and benches with exposed coal in some places. The rehabilitated section presented as a 1:3 incline constructed from cut-and-fill by down-dozing a mixture of red and grey soils from above the batters, compacted in low thickness layers and checked for final moisture content and density (Figure 4).

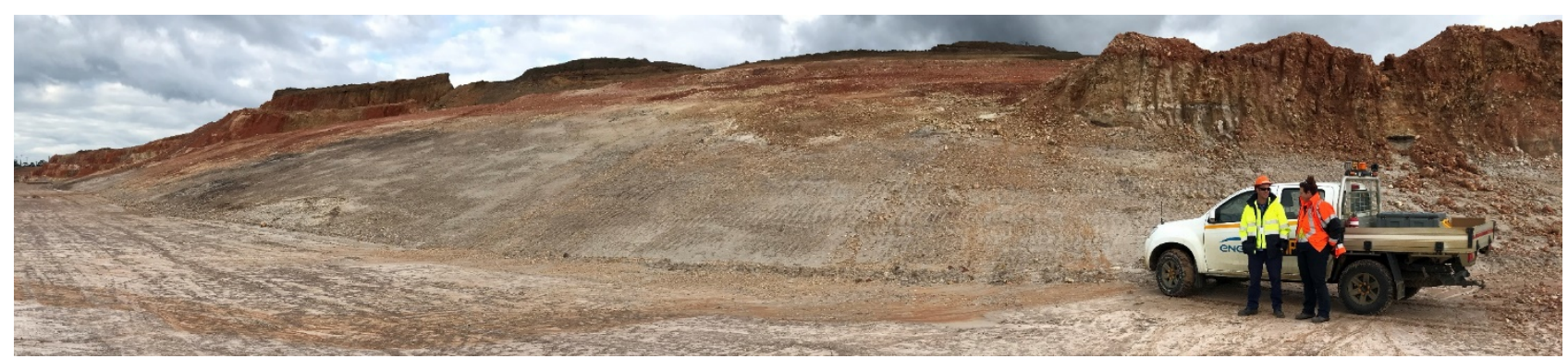

Figure 4 Panoramic view of Eastern Batter looking east

Sediment samples were specifically taken from materials that have been used to start construction of the EB shoreline area. Samples were taken at four sampling sites from the final predicted water level for the EB domain (Figure 3). A representative area of sediment was excavated by hand to a depth of $10 \mathrm{~cm}$ and stored in a plastic bag (Figure 5). Sediments were analysed for particle size distribution to below $70 \mu \mathrm{m}$ by hydrometer analysis (Australian Standards Method AS1289.3.6.3).

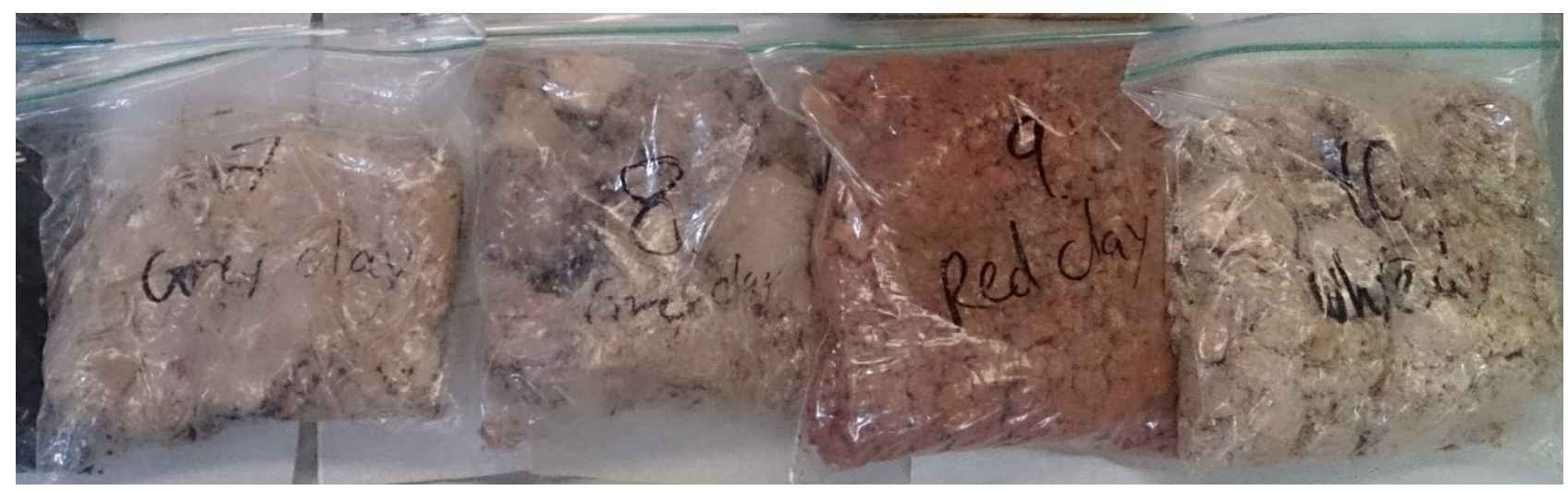

Figure 5 Sediment samples collected from Hazelwood Eastern Batter locations

Samples showed a range of silty clays through to a sand/gravel mixture and a wide range in their physical size distributions (Figure 6). Many sediments were classified as silty clay but also contained significant proportions of sand and gravel. The median grain size $\left(D_{50}\right)$ for these four locations varied greatly between approximately 10 and $300 \mu \mathrm{m}$ (Table 1 ). 

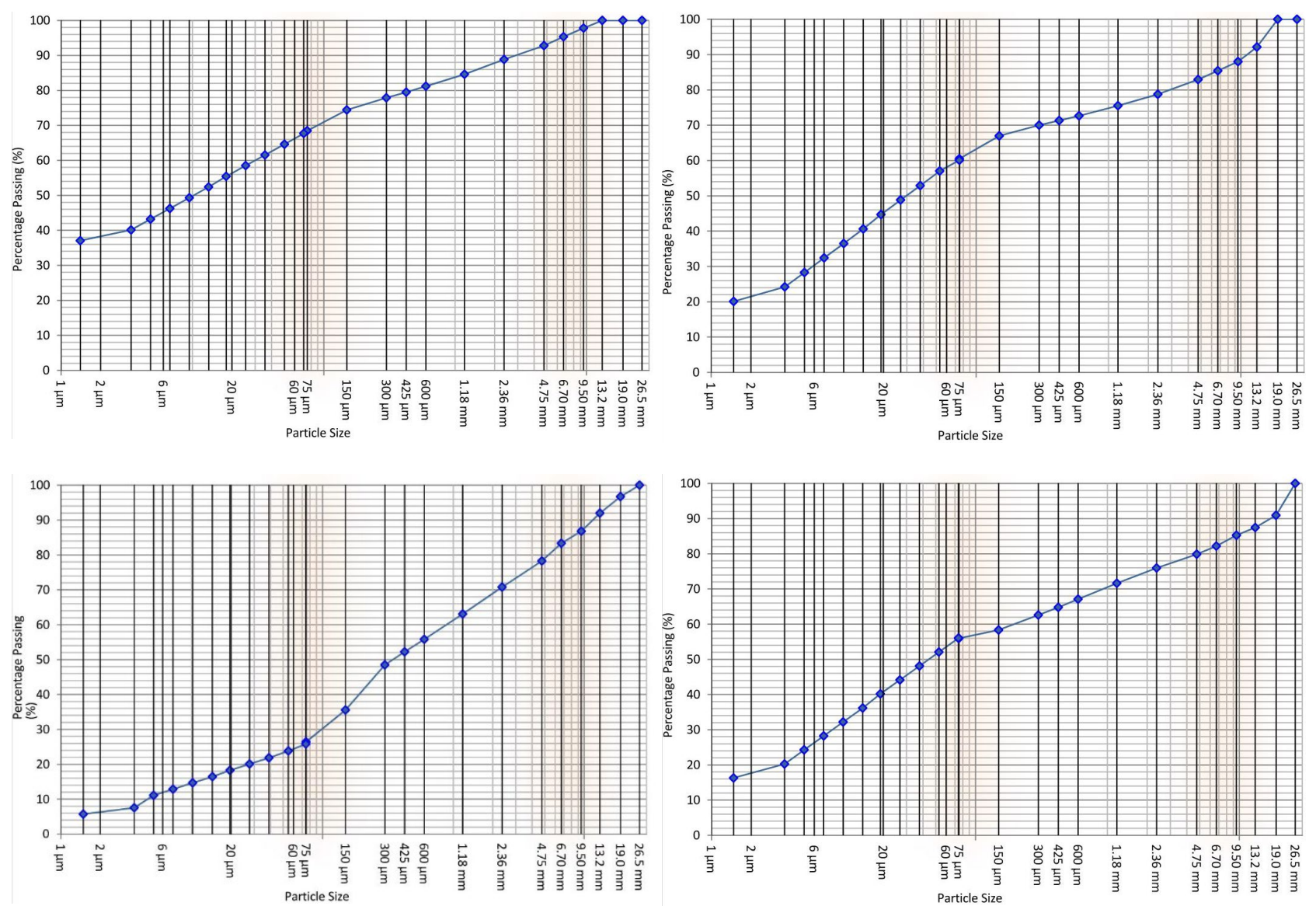

Figure 6 Particle size distributions (PSDs) for sediment samples

Table 1 Sediment sample results

\begin{tabular}{clc}
\hline Site & Description & $\mathbf{D}_{50(\mathrm{~mm})}$ \\
\hline 1 & Silty clay, with sand and gravel, grey, moist & 0.01 \\
2 & Silty clay, with gravel and sand, grey-beige, moist & 0.03 \\
3 & Silty clay, red-brown, moist & 0.36 \\
4 & Silty clay, with sand and gravel, pale grey-beige, moist & 0.047 \\
\hline
\end{tabular}

Bathymetry survey data was obtained from entire ENGIE pit void models and consisted of high-resolution point data from the final void shell overlain with the proposed EB shoreline design (Figure 7). 


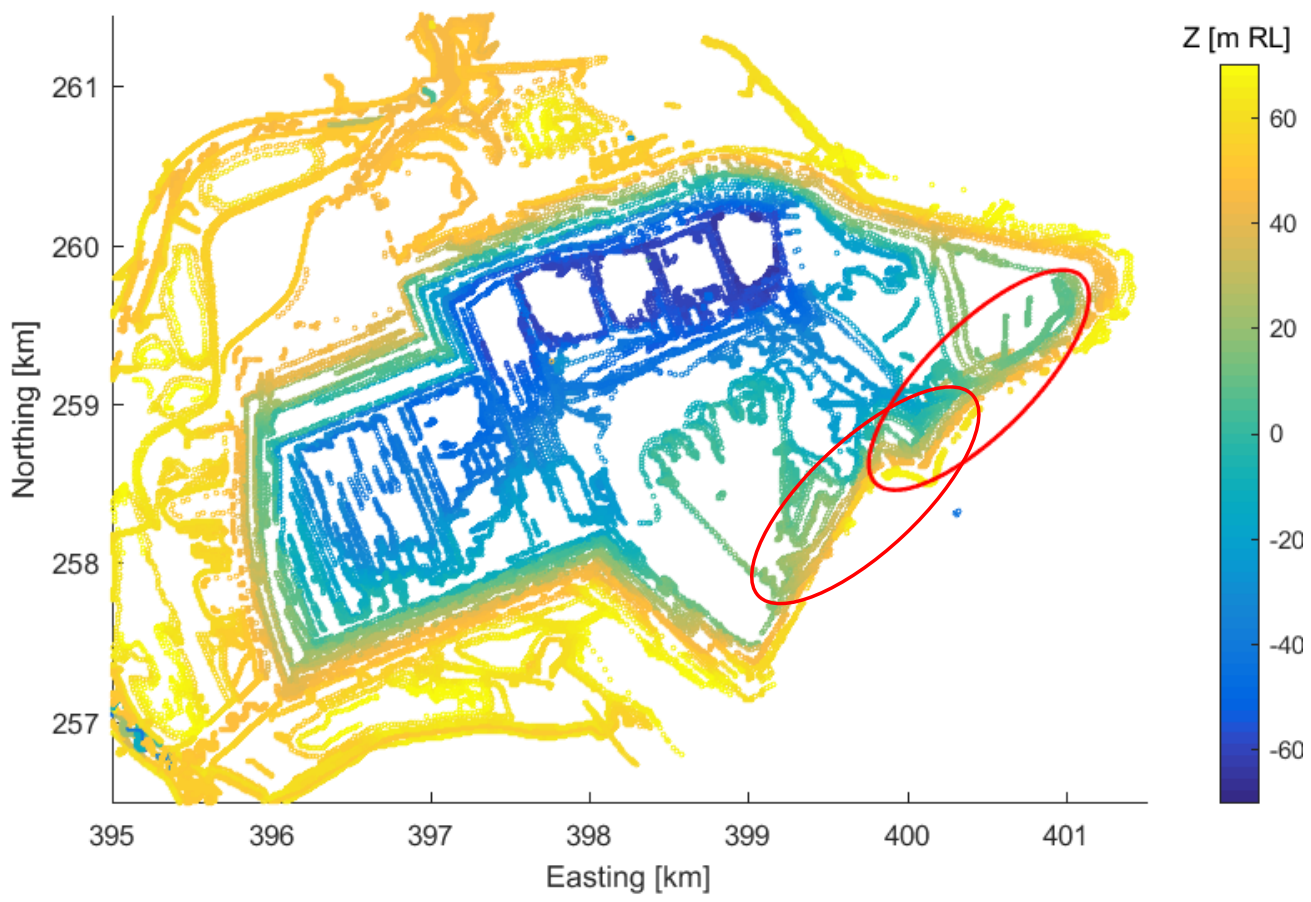

Figure 7 Final Hazelwood pit void bathymetry including design slopes. The Eastern Batter area is shown in the red ellipse

\subsection{Predictive numerical modelling}

Local wind data for the last 3.5 years was provided by ENGIE for three site weather stations (locations indicated in Figure $8(a)$ ). Wind rose plots from the data provide an indication of a prevailing wind speed and direction (Figure $8(b)$ ). Measured wind varied significantly among the different stations, particularly for the station next to the clean water pump station (CWPS, located on the mine floor) compared to the North and Mobile stations located at ground level (approximately 1-2 $\mathrm{m}$ above-ground).

Wind statistics based on data from the past five years measured by the Bureau of Meteorology (BOM) at a permanent weather station at Latrobe Valley Airport were also compared to site data (Figure 8(c)). The BOM site is located approximately $7 \mathrm{~km}$ away and showed slightly higher wind velocities. These higher velocities are likely due to being measured a standard $10 \mathrm{~m}$ off the ground. As this standard measurement height is required by Delft3D BOM data were used.

A number of scenarios were identified based on the type of sediment, the lakeshore slope, and the hydrodynamic forcing conditions (prevailing or storm event, Table 2). Each scenario was run for one year except for the storm scenario, which lasted three days. Given the exceedance probability of approximately $1 \%$, per annum this frequency was considered representative for a year. For all simulations, the lake water level was set at predicted long-term pit lake depth of $R L+45 \mathrm{~m}$, as advised by related water balance modelling work (this full pit lake level is still yet to be agreed with the mining regulator). 


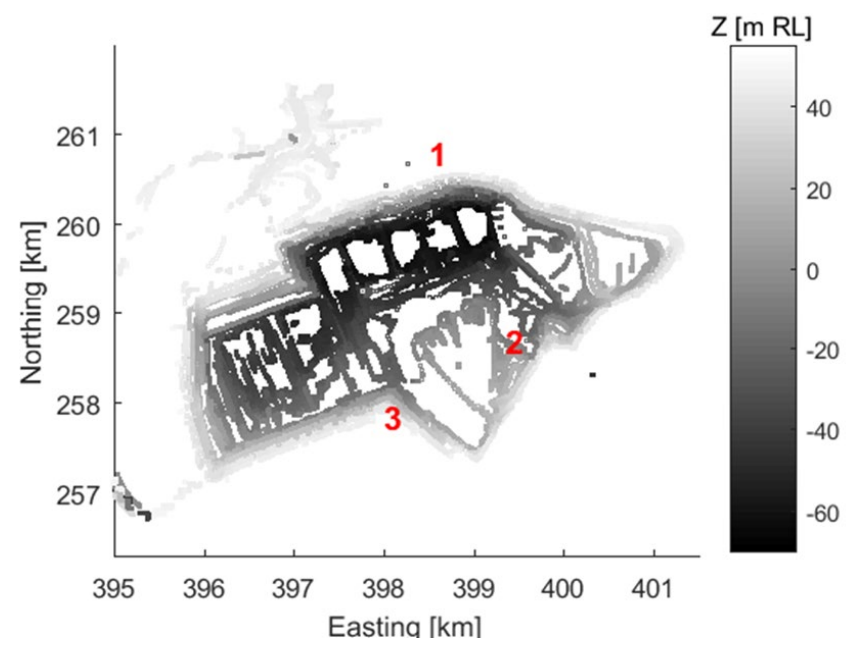

(a)
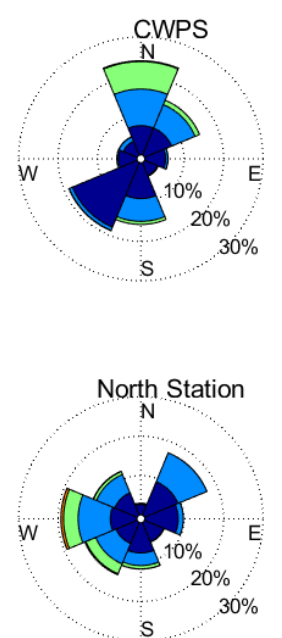

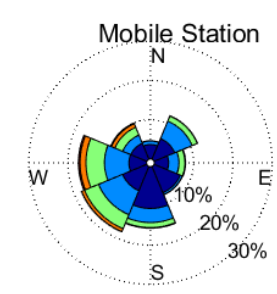

Wind speed

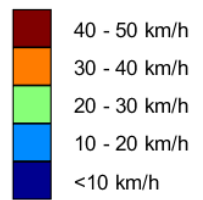

(b)

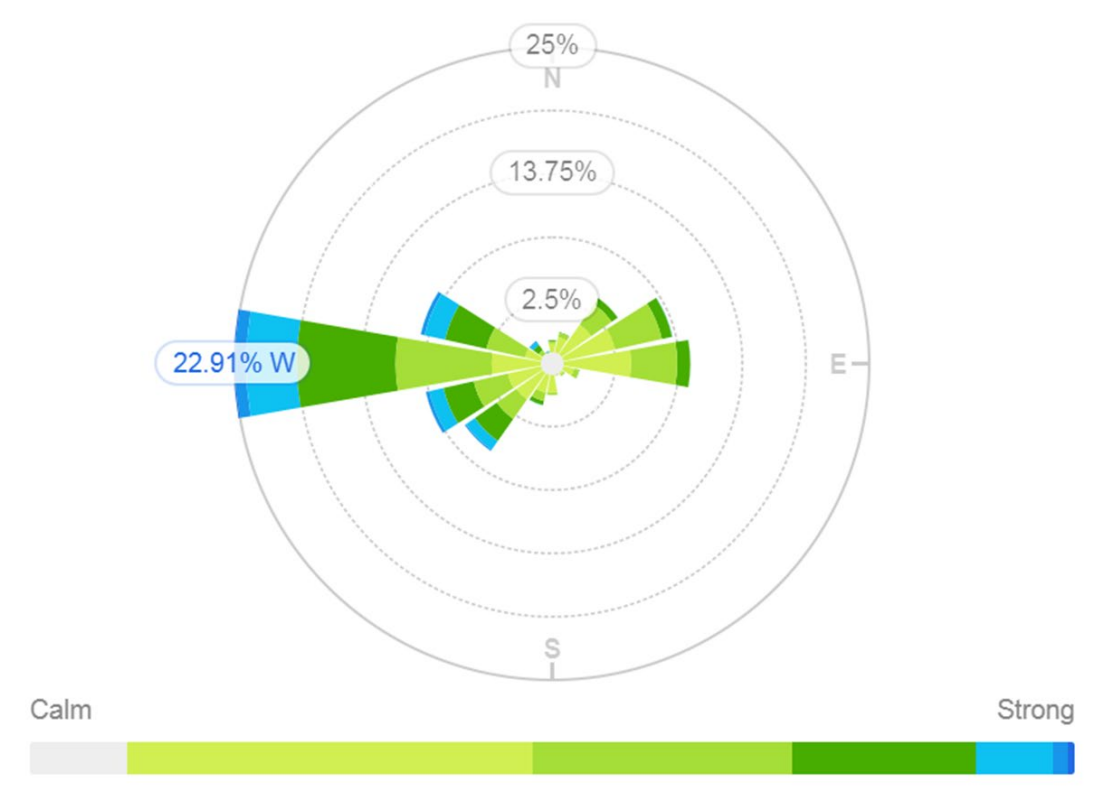

(c)

Figure 8 (a) Hazelwood site wind monitoring stations; (b) Wind rose plot derived from wind data measured locally by ENGIE; (c) By Bureau of Meteorology over the past five years at Morwell (BOM 2018)

The lakeshore slope is currently designed at $17^{\circ}$ from horizontal, primarily based upon geotechnical stability, and formed the base scenario in our modelling. One of the objectives of the current study is to assess the sensitivity of the simulated shoreline erosion to the initial slope, hence simulations were carried out with a more gentle $\left(12^{\circ}\right)$ and steeper slope $\left(22^{\circ}\right)$. Here we assume that the slope extends over the entire part of the profile that is morphodynamically active, to exclude any effects of variation in orientation along the slope. In practice, the eventual design water level may differ from the current design level ( $R L+45 \mathrm{~m}$ ), but as long as the design slope angle will be translated along the profile accordingly, this will not have any significant effect on predicted erosion rates. 
Table 2 Scenario combinations tested

\begin{tabular}{|c|c|c|c|}
\hline Run ID & Shore slope & Sediment & Wind condition \\
\hline 1 & \multirow{3}{*}{$\begin{array}{c}17^{\circ} \\
\text { (design) }\end{array}$} & Grey clay (cohesive) & \multirow{9}{*}{$20 \mathrm{~km} / \mathrm{hr} \mathrm{W}$ (prevailing) } \\
\hline 2 & & Red sediment (non-cohesive) & \\
\hline 3 & & Mixed (design) & \\
\hline 4 & \multirow{3}{*}{$12^{\circ}$} & Grey clay (cohesive) & \\
\hline 5 & & Red sediment (non-cohesive) & \\
\hline 6 & & Mixed (design) & \\
\hline 7 & \multirow{3}{*}{$22^{\circ}$} & Grey clay (cohesive) & \\
\hline 8 & & Red sediment (non-cohesive) & \\
\hline 9 & & Mixed (design) & \\
\hline 10 & $\begin{array}{c}17^{\circ} \\
\text { (design) }\end{array}$ & Mixed (design) & $40 \mathrm{~km} / \mathrm{hr} \mathrm{W}$ (storm) \\
\hline
\end{tabular}

Sediment scenarios represented construction of the EB shoreline with three different sediment types. The more common grey clay sediment representing the greatest proportion (ca. 80\%), and a red sandy gravel mixture representing a smaller proportion (ca. 20\%) of cover of the current EB shoreline. Grey clays were much finer and more cohesive than the red gravelly sands.

In order to assess the effect of sediment material on shore erosion three scenarios were simulated for two extremes and a more realistic situation with a mixture of both types:

1. Cohesive sediment: clay.

2. Non-cohesive sediment: sand.

3. Mixed sediment: an evenly-mixed combination of sediment both types.

The erosion and transport properties of sand can be predictively modelled using well-established sand transport formulations (van Rijn 2007a, 2007b) used in our study. However, the erosion, transport and deposition of clays are strongly site-specific. Clay erodibility and settling depends on the environment (low or high energy, salt or fresh) and history (influencing the degree of mud compaction). In consolidated form (as in Figure 5), clay will not be resuspended by fairly low energy conditions prevailing in pit lakes. However, the areas prone to erosion are continuously saturated. This allows the clay-dominated sediment to gradually swell, leading to an exposed clay layer that is erodible. We parameterised this behaviour with a lower critical shear stress for erosion $\left(\tau_{c r i t}=0.1 \mathrm{~Pa}\right)$, but also a relatively low erosion parameter.

\section{$3 \quad$ Results}

\subsection{Wave height}

Wave height across the lake and into EB was calculated by the model based on the selected scenario wind conditions. For the expected westerly prevailing and storm winds, representative wave height (measured from wave crest to trough) increases from West to East up to a maximum of about $0.2 \mathrm{~m}$ for prevailing conditions (i.e. $20 \mathrm{~km} / \mathrm{hr}$ wind) and $0.5 \mathrm{~m}$ for storm conditions (corresponding with $40 \mathrm{~km} / \mathrm{hr}$ winds) (Figure 9). 


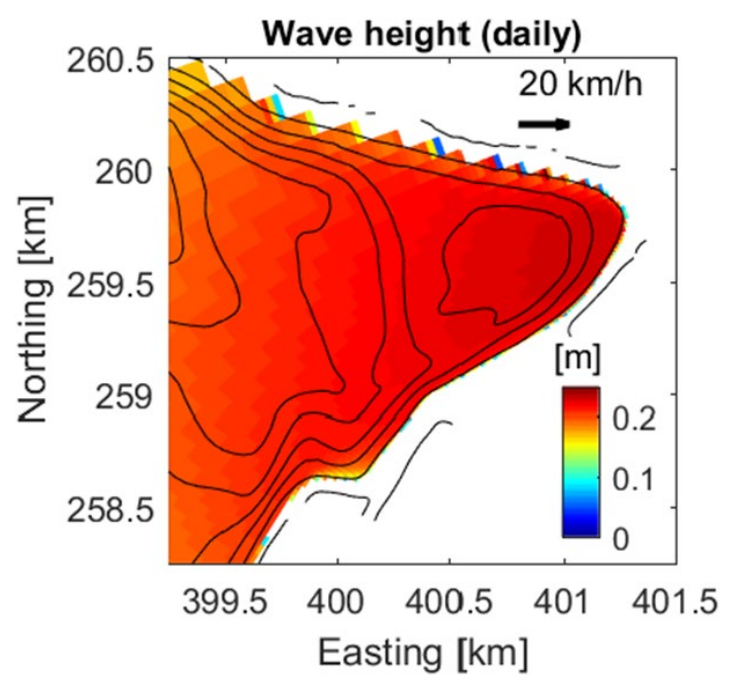

(a)

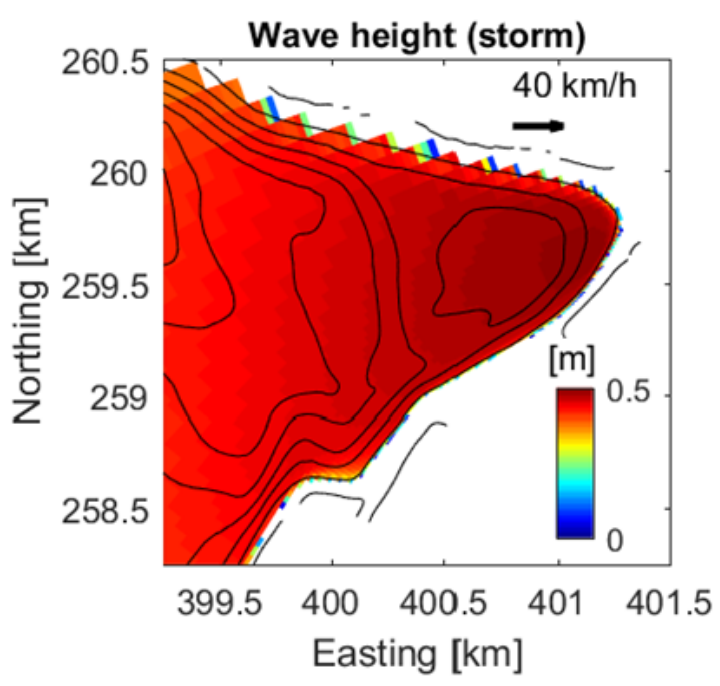

(b)

Figure 9 Simulated wave height across the lake for (a) prevailing conditions; (b) storm conditions

\subsection{Effect of shore composition and slope angle}

The initial and final profile after one year of simulation are shown for different regrade angles scenarios with prevailing conditions (Figure 10).
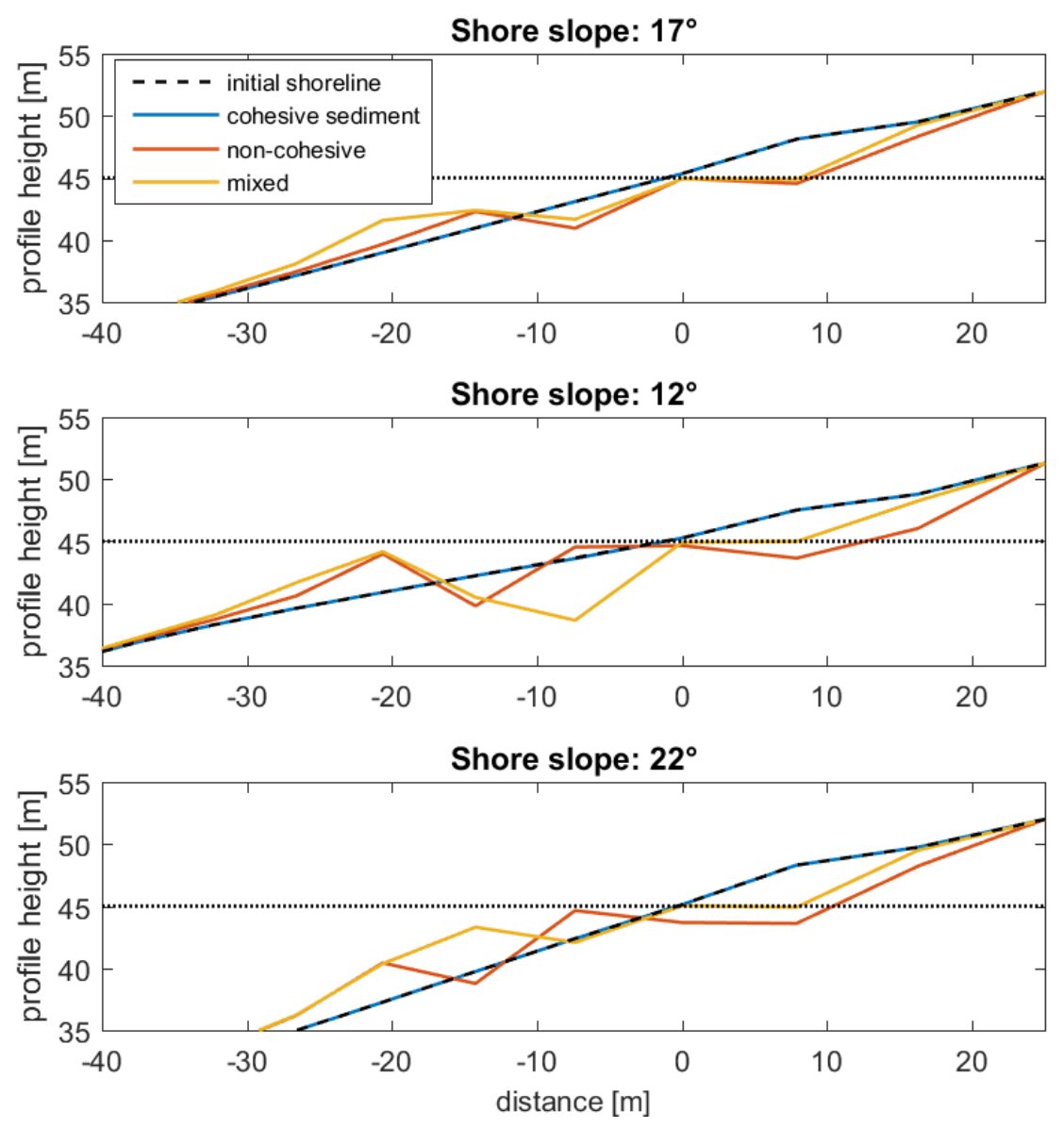

Figure 10 Effect of soil composition on simulated profile changes for all scenarios with prevailing conditions (the design lake level is indicated by the dotted line) 
Although the choice of parameters for the cohesive (clay) sediment case was rather conservative (i.e. $\tau_{\text {crit }}=0.1 \mathrm{~Pa}$, typically representative for loose muds), the hydrodynamic forcing under prevailing conditions is so low (Figures 3 and 9) that there is still negligible effect of the waves on the shore, independent on the slope itself (Figure 10, final profile overlaps initial profile). In contrast, when assuming fully non-cohesive sediment (sandy gravels) the model shows a clear erosion pattern for all cases. Non-cohesive sandy sediment is also mobilised from the dry part of the slope, which results in retreat of the shoreline. The results for mixed sediment are similar to the results with non-cohesive clay sediment only. Mixed sediment led to slightly lower erosion rates.

Figure 10 shows that the shore slope particularly affected the long-term erosion depth. Erosion rates were least for the gentle slope $\left(12^{\circ}\right)$ scenario. This is expected as there is a greater distance up-shore that is available for the waves to dissipate their energy when reaching the shoreline. This greater energy dissipation resulted in relatively low bed shear stress and consequently relatively low sediment transport rates. Nevertheless, shoreline retreat remained the same at around 20-25 m for clay sediments. This is likely caused by some of the model assumptions and limitations that are used here. For instance, it is expected that for steeper slopes, soil stability plays a bigger role and should be studied in more detail and accounted for in the model (e.g. through parameterisation). Also, wave run-up and wave reflection may become more important on steeper slopes and are presently not included in the model. Finally, although the current grid resolution is very fine for typical Delft3D applications ( $\sim 5 \mathrm{~m}$ in cross-shore direction), it may still be too coarse to accurately represent the steep mine pit slopes.

\subsection{Erosion during storm event}

Highly energetic wave formation during storm events typically plays a significant role in the erosion of shorelines. Under high-energy storm wave conditions, the shoreline was eroded throughout the EB domain (Figure 11). However, the erosion rates during this three-day event were of similar magnitude compared to one year of average conditions, and mixed sediments showed a retreat of only between 10-15 m. The actual erosion rate contains significant uncertainty with the current state of these models, but given the relatively steep shores, as well as the findings from other similar mine lakes, shore erosion of several metres during a storm event is considered realistic.

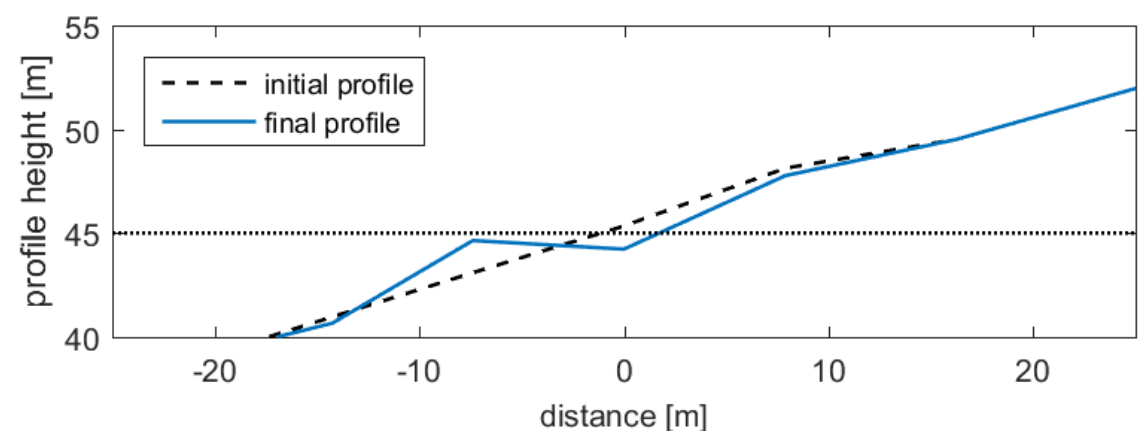

Figure 11 Profile development for the $17^{\circ}$ design shore slope with mixed sediments following a storm event (the design lake level is indicated by the dotted line)

\section{$4 \quad$ Conclusion and recommendations}

Shoreline erosion modelling is just one aspect of broader pit lake catchment rehabilitation and erosion management, which often must consider alternative slope geometries (McPhail \& Rye 2008). By not requiring the specific formative conditions that some models require (e.g. alluvial analogues, Kelder et al. 2016), our approach can suit most conceivable sites. However, other considerations such as design and construction of inflow/outflows, islands and embayments, riparian and littoral zones may also require consideration in pit lake shoreline design. 


\subsection{Model findings}

The model was established with a relatively low amount of input data and calibration data. However, the study revealed the following key points:

- The shore eroded in key areas exposed to locally generated wind waves.

- The $12^{\circ}$ slopes did not show substantially decreased erosion rates compared to design $17^{\circ}$ slopes. However, $22^{\circ}$ slopes showed substantially greater erosion. Because of this relative erosion rate increase, the design $17^{\circ}$ slopes appear to be more erosion-resistant than steeper slopes, but not necessarily significantly less resistant than lower angle slopes.

- Non-cohesive sediment (sandy gravel) eroded from the shore was transported and deposited in slightly deeper water, leading to gradual stability of the shore. Clay-dominated sediments, however, were more difficult to erode and, once eroded, settle at a greater distance in very quiet conditions (typically the deepest part of a lake). Contrary to shorelines with non-cohesive sediments, erosion of clay-dominated shorelines will therefore generally not be reduced over time through re-establishment of equilibrium profiles.

- The cohesion of clay sediments resulted in the lowest erosion rate. Having mixed sediment influenced erosion rates, resulting in a slight decrease of erosion from sandy gravel sediment alone.

- Erosion rates during storm conditions were higher (expressed per unit of time) compared to average conditions, but their overall behaviour was not different to that of prevailing wind conditions. Consequently, slope and sediment characteristic management to mitigate storm wind erosion can be similar to those used for mitigating prevailing wind erosion.

\subsection{Study limitations}

Complex numerical models, such as Delft3D, can predict the hydrodynamic forcing with a fairly large level of certainty. The resulting transport rate of sand-sized particles can be computed with a fairly large accuracy as well. However, there are currently significant limitations in the current work.

One limitation is related to the erodibility of consolidated and dry mixtures of clay, sand, and larger aggregates. The erosion rate of wet, consolidated clays is determined by its capacity to swell and liquefy, but changes irreversibly when the soils become dry (as the eroding embankments), especially with an additional sand fraction. The combined impact of the clay mixture and drying processes result in a poor predictability of soil erodibility.

Another uncertainty is related to slope effects. The role of the bed slope on transport is not accounted for in the current model set-up. Simple formulations for bed slope effects do exist in Delft3D, but should preferably be calibrated with observations of bed level change.

\section{Acknowledgement}

We acknowledge the support of ENGIE in this project and specifically Hazelwood Mine staff Luke de Garis, Romeo Prezioso, Antonia Scrase (Rehabilitation and Closure Plan Manager), and James Faithful (Technical Services Manager - Mine) who reviewed this paper.

\section{References}

Bureau of Meteorology (BOM) 2018, Morwell (La Trobe Valley Airport) climate averages, viewed 24 August 2018, http://www.bom.gov.au/climate/averages/tables/cw_085280.shtml

Castendyk, D \& Eary, T 2009, 'The nature and global distribution of pit lakes', in D Castendyk \& T Eary (eds), Mine Pit Lakes: Characteristics, Predictive Modeling, and Sustainability, Society for Mining, Metallurgy, and Exploration, Colorado.

de Lange, WJ, Genthe, B, Hill, L \& Oberholster, PJ 2018, 'Towards a rapid assessment protocol for identifying pit lakes worthy of restoration', Journal of Environmental Management, vol. 206, pp. 949-961. 
Deltares 2014, Delft3D Hydro-Morphodynamics, User Manual - Simulation of Multi-dimensional Hydrodynamic Flows and Transport Phenomena, Including Sediments, Deltares, Delft, $710 \mathrm{p}$.

Doupé, RG \& Lymbery, AJ 2005, 'Environmental risks associated with beneficial end uses of mine lakes in southwestern Australia', Mine Water and the Environment, vol. 24, pp. 134-138.

Gourlay, T 2011, Notes on shoreline erosion due to boat wakes and wind waves, CMST research report 2011-16, 10 p.

Hazelwood Mine Fire Inquiry 2016, Hazelwood Mine Fire Inquiry Report, Melbourne, 252 p.

Kalin, M \& Geller, W 1998, 'Limnological fundamentals of acid mining lakes', in W Geller, H Klapper \& W Salomons (eds), Acidic Mining Lakes, Springer, Berlin.

Kelder, I, Waygood, CG \& Willis, T 2016, 'Integrating the use of natural analogues and erosion modelling in landform design for closure', in AB Fourie \& M Tibbett (eds), Proceedings of the 11th International Conference on Mine Closure, Australian Centre for Geomechanics, Perth, pp. 99-106.

Lund, MA \& McCullough, CD 2011, 'Meeting environmental goals for pit lake restoration - factoring in the biology', in CD McCullough (ed.), Mine Pit Lakes: Closure and Management, Australian Centre for Geomechanics, Perth, pp. 83-90.

McCullough, CD 2016, 'Key mine closure lessons still to be learned', in AB Fourie \& M Tibbett (eds), Proceedings of the 11th International Conference on Mine Closure, Australian Centre for Geomechanics, Perth, pp. 319-332.

McCullough, CD, Hunt, D \& Evans, LH 2009, 'Sustainable development of open pit mines: creating beneficial end uses for pit lakes', in D Castendyk \& T Eary (eds), Mine Pit Lakes: Characteristics, Predictive Modeling, and Sustainability, Society for Mining, Metallurgy, and Exploration, Colorado.

McCullough, CD \& Lund, MA 2006, 'Opportunities for sustainable mining pit lakes in Australia', Mine Water and the Environment, vol. 25, pp. 220-226.

McCullough, CD, Lund, MA \& Zhao, LYL 2010, Mine Voids Management Strategy (I): Pit Lake Resources of the Collie Basin, Department of Water Project Report MiWER/Centre for Ecosystem Management Report 2009-14, Edith Cowan University, Perth, 250 p.

McCullough, CD, Schultze, M \& Vandenberg, J 2018, 'Realising beneficial end uses for pit lakes', in C Drebenstedt, F von Bismarck, AB Fourie \& M Tibbett (eds), Proceedings of the 12th International Conference on Mine Closure, Technical University Bergakademie Freiberg, Freiberg, pp. 487-494.

McCullough, CD \& van Etten, EJB 2011, 'Ecological restoration of novel lake districts: new approaches for new landscapes', Mine Water and the Environment, vol. 30, pp. 312-319.

McPhail, G \& Rye, C 2008, 'Comparison of the erosional performance of alternative slope geometries', in AB Fourie (ed.), Rock Dumps 2008: Proceedings of the Fifth International Seminar on the Management of Rock Dumps, Stockpiles and Heap Leach Pads, Australian Centre for Geomechanics, Perth, pp. 277-288.

Read, J \& Stacey, P 2009, Guidelines for Open Pit Slope Design, CRC Press, 510 p.

Ross, T \& McCullough, CD 2011, 'Working near pit lakes - health and safety considerations', in CD McCullough (ed.), Mine Pit Lakes: Closure and Management, Australian Centre for Geomechanics, Perth, pp. 167-182.

Schultze, M, Castendyk, D, Wendt-Potthoff, K, Sanchez-Espana, J \& Boehrer, B 2016, 'On the relevance of meromixis in pit lakes - an update', in C Drebenstedt \& M Paul (eds), Proceedings of the IMWA Conference 2016, International Mine Water Association, Freiberg, pp. 199-200.

van Etten, EJB 2011, 'The role and value of riparian vegetation for mine pit lakes', in CD McCullough (ed.), Mine Pit Lakes: Closure and Management, Australian Centre for Geomechanics, Perth, pp. 91-106.

van Rijn, LC 2007a, 'A unified view of sediment transport by currents and waves, part I: initiation of motion, bed roughness and bed load transport', Journal of Hydraulic Engineering, ASCE, vol. 33, pp. 649-667.

van Rijn, LC 2007b, 'A unified view of sediment transport by currents and waves, part II: suspended transport', Journal of Hydraulic Engineering, vol. 33, pp. 668-689.

Vandenberg, J \& McCullough, CD 2017, 'Key issues in mine closure planning for pit lakes', in N Nanthi Bolan, Y Ok \& M Kirkham (eds), Spoil to Soil: Mine Site Rehabilitation and Revegetation, CRC Press, Australia. 
